\title{
Language Use in Ìdààmú Páàdì Mínkáílù: A Yoruba Religio-Satiric Play
}

\author{
Adagbada Olufadekemi \\ Department of Nigerian and Foreign Languages and Literatures,Faculty of Arts,Olabisi Onabanjo University, Ago-Iwoye, Nigeria \\ *Corresponding Author: fadek001@yahoo.com
}

Copyright $@ 2013$ Horizon Research Publishing All rights reserved.

\begin{abstract}
Literary satire is generally a social pre-occupation; an attempt to contribute to the advancement of a society in all the ramifications of the word. This is done by humorously pointing out individual or collective non-conformation to accepted norms and ethos. The task however demands subtlety, especially when operating from a multi-religious and multi-ethnic society like Nigeria. It therefore calls for a great ingenuity especially in the use of language by the satirist who must bring his ideal to the fore. In the view of Sociolinguistics, this paper submits that in Idaamu Paadi Minkailu under study, Adebayo Faleti can draw out from the reader a mirthless laughter in the confusion and agitation faced by a Catholic priest and elder statesman, who must not divulge the confession of a repentant member of his congregation, but must also ensure the obedience to, and the maintenance of the social order in his society. The satirist's bias and the probable reasons for it are highlighted in this paper.
\end{abstract}

Keywords Religion, Social order, Crime, Humour, Language

\section{Introduction}

Language, a process peculiar to human beings, is for sharing information, ideas, thoughts and emotions between a source and a receiver. This is to bring about mutual understanding; reducing uncertainties about taking the proper actions (expected). Language therefore involves the process of coding and decoding of message(s) between a speaker and his/her listeners. These break down to other elements as source, transmitter, message, channel, destination/receiver and feedback [1]. Man, being the only speaking animal, has made language to be defined as:

\footnotetext{
Human vocal noise or the arbitrary graphic representation of the noise used systematically and conventionally by members of a speech community for the purpose of communication [2].
}

Language is not experienced in isolation; otherwise it would not be recognized as language. Rather, it is always in relation to an occurrence; some background of persons and actions and events from which things are said to derive their meanings [3]. It is of utmost importance therefore, to have knowledge of the environment in which a speech event takes place so that the pragmatics of an utterance, spoken or written, is understood [4]. Among sociolinguistics, this is referred to as "context of situation", a term associated with proto-pragmatists, especially Firth Malinowsky [5] and Levinson [6]. The term is wide and varied in nature and texture. Its content may be physical or concrete and immediate, while some others may be psychological, abstract and remote. Mey (2004), in the views of a pragmatist opines 'context' to mean "all the factors that play a role in producing and understanding utterances" [7]. To Levinson cited above, while summarizing Lyons's (1977) view about "Knowledge", opines that features shared by participants in a speech event as roles and status, spatial and temporal location to formality level, medium to channel and subject matter and domain, determines the register of a language.

It is imperative therefore to understand that the figures of speech employed by a literary artist, especially a playwright in the use of words, phrases on sentences, are purposeful. This is to secure strength of feeling or thought that cannot be had in its ordinary use. Figures of speech are therefore used to make descriptions vividly clear and real to life. This helps to present ideas in concrete terms. They also add beauty and intensity of effect to speeches and other writings [8].

The focus of this paper therefore is to examine to what effect Adebayo Faleti has used language to satirically drive home the travails that can befall a Catholic priest, as both a cleric and a community leader in İdààmú Páàdì Mínkáílù (The Travails of Rev. Father Michael)

\section{The Yoruba: Origin, Geography and Language}

Sole oral tradition had earlier pointed out the Yoruba South-West as descendants of Oduduwa - a heroic progenitor, and Ile-Ife (now in Osun State, Nigeria) as their place of origin. However, a combination of myths, oral tradition, archaeological discoveries and linguistic evidences 
in more recent researches [9] have shown that the (agrarian) Yoruba in their transmigration from the area of the Rift Valley in Eastern Africa, to Northern Africa (at at a time when the Sahara Desert was not a desert but a country of green land with rivers and streams) and finally to Western Africa, had been slowly, over hundreds of thousands of years ago. Evidence of human existence in the area now known as Nigeria today, dates 40,000 years ago- that is about 38,000 BC [10]. By 2000 BC- 1,000 BC, the Yoruba had emerged as a distinct language group from the Kwa group. By that time, they had moved from the Niger-Benue confluence (the home of the kwa language), and Ile-Ife was one of the most important places of settlement in their exodus, after the people had acquired distinctiveness and self-awareness as a separate language group [11].

Today, (the formerly wandering)Yoruba tribe, one with the largest speech community of the three most (officially) recognised languages in Nigeria[12] (the other two being Igbo and Hausa), is settled predominantly in Lagos, Ogun, Oyo, Osun, Ondo, Ekiti and some parts of Kwara states of Nigeria as sub-ethnic groups. Some of these are Oyo, Ijebu, Ekiti, Ijesa, Ife, Ondo, Ikale, Egba, Ibarapa, Egbado, Akoko, Owo, Bunu,Yagba, Gbede, Ikiri,, Ketu, Awori, Sabe, Owe and Ibolo. Each of these sub-ethnic groups has peculiar variant form of Yoruba Language as their dialect, but they jointly use the standard form of Yoruba Language (Yoruba Ajumolo) as the official variety for teaching, writing, news or reports.

Slave trade, partitioning of West African land by Europeans colonists and self-willed migration in search of greener pastures, have also made it inevitable to find Yoruba descendants far afield in other West African states like Republic of Benin, Togo, Ghana, Sierra Leone, and Ivory Coast. They can also be found off-shore in Brazil, Cuba, Haiti, United States of America and Trinidad and Tobago. In these foreign lands generally, the Yoruba descendants are using their heritage for rebirth and collective affirmation by annexing mythologies to create ideologies of acculturation for Yoruba identity, thereby constructing a cultural presence that cannot be ignored [13].

The (standard) Yoruba language is a total one with its vocabulary built-up of largely monosyllabic words. The tones are High, Middle and Low. Yoruba is essentially a spoken language because most of the people to whom the language is native, are non-lettered. The Yoruba through the ages, places great emphasis on oratorical skills [14]. A good orator is known as Ameso (one who knows how to speak). For this, the language makes great use of figure of speech technique in the building up of vocabulary. The figurative extension of the use of a word to cover other meanings besides that for which it was originally coined, is carried further in Yoruba than European Languages [15].

The earliest attempt to condense Yoruba to writing was in 1817 by E.T. Bowdrch, a Christian missionary in Ghana, who meeting some Yoruba sojourners, was fascinated by their organised language, customs and traditions. This attempt opened a floodgate for other indigenous and foreign lovers of the language to start writing religious, historical and finally literary texts in Yoruba language.

\section{Religion, Literature and Satire of the Yoruba}

The Yoruba, like other Africans, have always had their own traditional (indigenous) religion which is monotheistic; a belief in Olódùmarè the most Supreme Being and the creator of all there is, who has other divinities as His aides [16]. Religion is the keynote of the Yoruba's existence; forming the foundation and all governing principles of their lives. Oral literature for instance, enshrines the theology and cosmology of the people, and reflects their ethos and moral values. This is why early Yoruba writers in their works, bear a carry-over of this traditional function in their literary creativities [17].

Being this religious, it is not surprising that the Yoruba received foreign religions like Christianity, Islam and other ones, from the West, East and other places respectively. The fact remains however, that the foreign religions have not been received and adopted hook, line and sinker, to completely replace the traditional religion of the people. In the spirit of Yoruba religio-cultural nationalism, there had been signs of rebellion against the modes, content and practice of the 'alien' and 'threatening' religions. Their (the religions) appearances of being 'fashionable' and that of the 'enlightened', and having enlarged the people's visions, liberated their minds from un-necessary fears and superstitious inhibitions, thereby giving them a progressive outlook and sense of personal values [18], has led to a kind of syncretism of Christianity and Yoruba tradition. Example of this is the birth of African Indigenous Churches.

Some modern Yoruba literary artists, in the vanguard of sustaining the credibility and relativity of the Yoruba traditional religion to the people, write creative works that attempt to highlight and bring to the fore, the 'inconsistency' and 'emptiness' of foreign religions to the socio-cultural reality of the Yoruba society. Playwrights for instance, more often than not, write satirical plays to point out this fact. Examples of such are Abe Aabo (Under protection) [19] and Alagba Jeremaya (Elder Jeremiah) [20].

Satire is described as "the use of humour, irony, exaggeration or ridicule to reveal and criticize people's bad point [21]. This is to say in effect that the major pre-occupation of satirists is to extol morality. Religion too, in the opinion of Glock and Stark [22] serves a similar purpose; that of supporting social solidarity and maintenance of social integration. The use of satire in rituals and festivals among the Yoruba rests on the belief that if the aberrant are exposed, the gods will be pleased with the land [23]. Humour is therefore directed intentionally to 'evil-doers' to deride them, in order to shame them into mending their ways, having behaved in conflicting manners to the accepted norms. This is what makes satire a social authority.

Operating in a (Nigerian) society that is undergoing political transition, the Yoruba playwright has a crucial role to play, a role that goes beyond creating recreation; that of 
creating awareness and passing caustic comments on his/her nation, as it moves towards the utopia. This is what makes it imperative for a religion - focused playwright to use satire as:

\begin{abstract}
...the expression in adequate terms of the sense of amusement or disgust excited by the ridiculous or unseemly, provided that humour is a distinctly recognizable element, and that the utterance is infested with literary form. Without humour, satire is invective; without literary form it is mere clownish jeering [24].
\end{abstract}

In the oral tradition, Yoruba satirist such as fools, jesters and rhapsodists, enjoy a lot of diplomatic immunity, for they have the society's backings to ridicule anybody, not excluding the monarchs. They are/were the community's mouth-free for checks and balances, the etymological derivation of Yoruba maxims like:

\section{$N$ ó wì í, oba kì í pòkorin \\ (I will speak; the king does not kill a poet)}

The individual person in present times is much less amenable to social control in the form of public opinion, than in the past. This is because the principal social control is the adopted British political and judicial systems, with their other peculiar functionaries. A literary satirist in contemporary times is more wary of litigation, and as such practice his art of ridicule, mockery, caricature, burlesque, derision, sarcasm, lampoon and parody, with tact and subtlety. İdààmú Páàdi Mínkáílù (The Travails of Rev. Father Michael) [25] is a good example of such written Yoruba satires. The synopsis of the play is given below.

\section{Synopsis: İdààmú Páàdì Mínkáílù (The Travails of Rev. Father Michael)}

Páàdì (Padre) Mínkáílù agrees to being co -opted as an ex-officio member of the Ejigbo Local Government Council, after an initial resistance. His piety and sincerity earns him the position, for he is nominated by king Elejigbo the Patron, Ibrahim; another executive member, Yunisa; the council secretary and Setilu; the treasurer. Consenting to the nomination, the State Governor sends the Reverend Father a letter of appointment. The term of reference for the committee is to put an end to the corrupt practices of the officials of the council secretariat. $£ 20,000$ is sent to the council, for the construction of a bridge over the Ajingodo River. Having a pre-knowledge of the arrival of the money, Yunusa, Ibrahim and Prince Salu jointly swear to an oath to prevent divulgence, and attempt to steal the money from Setilu; the hardworking and sincere treasurer. In the bid, Setilu is shot by the hoodlums. The money is not found by the robbers because in a premonition, Setilu already sends for his wife, who takes the money to Páàdì Mínkáílù's mission house. Tormented by his conscience , Prince Salu goes to confess stealing, murder and being a member of a secret cult to Páàdì Mínká ílù. As wont of Catholic Priests , Mínkáílù does not reveal Salu's crimes to the detectives who come to the town to investigate the incidence. This repression and Salu's refusal to hand himself over to the police, set in the conflicts of the play, leading to the death of the three armed robbers and that of innocent Prince Rafilu and Setilu, the hardworking and sincere treasurer.

\section{The Readings}

The complexity and the attendant sensitivity of the multi-religiosity of the Nigerian nation, makes it pertinent that a Nigerian playwright be tactical in the theme characterization, plot and the setting of his /her creativity . This is evident in Fálétí's İdààmú Páàdì Mínkáilù under study. The characters are given ambiguous names which may at a face value, not be directly ascribed to either Christian or Islamic origin. Christians are known to bear names of saints, angels or those of righteous people mentioned in the Bible. Examples of such are Mark, Paul, Luke, Gabriel, Raphael or Moses for males, and Ruth, Deborah, Elizabeth, Sarah, Hannah or Rebecca, for females. For the Muslims, four groups of names are approved by the Shar' (Islamic laws). These are Ubudiyyah (names that reflect the greatness of Allah) like Abdullah and Abd Ur-Rahman, (these names show that their bearers are ibad-servants and worshippers of Allah. The second group contains names with realistic meanings that portray being truthful and modest, like al-Harith (cultivator) and Hamman (planner). Another group is that which contains the names of the Prophet (SAW). Examples of these are Ahmad, Mahmud or Hunay. The fourth group are names of other prophets and other righteous people. Some of these are Musa, Isa, Abdullah, Urwah, Hamzar, Ja'far, Umar or Khalid [26]

In order not to be accused of partiality, Fálétí technologizes the names of the characters in the play in three different ways. First, he arabicalizes the Christian names in such a way that one initially sees them as Muslim names. They are as follows:

\section{Gabriel as Jubirilu (An Angel of God)} Sarah as Saratu (The biblical/koranic wife
of Abraham)

\section{Saul as Salu (The persecutor of Christians in the bible) \\ Rapheal as Rafilu (An angel of God) \\ Stephen as Sufianu (A master in the bible)}

Yunusa (Yunus) and Ibrahimu (Ibrahim) are purely Muslim names that have Christian equivalents and similar meanings (Job and Abraham respectively). Setilu's meaning as may be intended by the playwright is ambiguous . It is either meant to be the ambicalization of Seith (a biblical 
name), or Sétilu (as it is) an old traditional name believed to have been that of the blind diviner from Nupe, who brought Ifa divination system to Yoruba land [27]. The second option is likely to have been upheld in the light of Setilu's protagonist's role in the play.

The figures of speech employed by the playwright in his satire are Resemblances like simile, metaphor, and personification. He also used Associations like hyperbole, apostrophe and metonymy. The Contrasts that can be found in the play are antithesis, irony, paradox and epigrams. $\mathrm{He}$ also makes use of other literary devices like word -play, dramatic irony repetition , onomatopoeia, rhetorical questions, soliloquy and also dialect , loaned and archaic words. To situate the play in Yorùbá religio -social background, he also used Yorùbá oral poetry like ofo (incantations) and orin (songs).

\section{Resemblances}

The Yorùbá people have a lot of respect for the aged and the clerics. Such people are not only assumed to be wise, but also honest, being priests or priestesses, who know the spiritual implication of vices. Such people are usually entrusted with the custody of other persons' precious items. In modern times, the socio-cultural changes as seen in the increase of vices like theft, lying, greed and injustice, which have brought about the lack of respect for traditional norms and values, is making many elders to shun this type of responsibility. This is why Páàdì Mínkáílù tells Saratu not to compare him (in a simile) with a bank, when the latter takes the $£ 20,000$ meant for the bridge construction to his (the Padre's) vicarage. He says:

\section{Èmí jé bi banki ni àbí tèwo?}

(Do I look like a bank or what?)

King Jùbìrílù's statement that

$$
\begin{array}{r}
\text {...Bókùn emi yi bi ìpèti } \\
\text { (p. 79) }
\end{array}
$$

\section{(... If one's life is as thick as a rope...)}

is another simile in the text.

Metaphorical statements are also used by the playwright . For instance, Mínkáílù compares his burden as a member of the local council committee to the cross that Jesus bore on the way to Calvary, when He was to be hanged. In his acceptance speech, he says:

$$
\begin{aligned}
& \text { Mo gba agbelebu náà (pg. 6) } \\
& \text { (I accept to bear the cross) }
\end{aligned}
$$

Another metaphor is seen in page 77 of the text when Yunusa says:

Nitori naa, bi mo ba kó firí agutan kan

\section{nitosi nihin-in igbehin re kò nii da'a o.}

$$
\begin{aligned}
& \text { (As such, if I catch the glimpse of any } \\
& \text { sheep here, the aftermath will be } \\
& \text { unpleasant) }
\end{aligned}
$$

In the Yorùbá traditional religion, an initiate of a cult is known as awo (custodian of secrets), while a non-initiate is referred to as àgùtàn; a sheep. What Yunusa means here is that he is ready to kill anyone who may want to spy on them.

In the curtain speech by Mínkálíu at the end of the play , while lamenting Setilu's death, he personifies death and sickness, and also mocks death by seeing Setilu's demise as the peaceful sleep of a good person. He says:

$$
\begin{aligned}
& \text { Ikú kò me'ni àa pa } \\
& \text { Arùn kò me'ni àá lu... } \\
& \text { E wá w'atisun eni're } \\
& \qquad \text { (pg. 91) } \\
& \text { Death knows not who to kill } \\
& \text { Sickness knows not who to club... } \\
& \begin{array}{l}
\text { Come and see the slumber of a good } \\
\text { person }
\end{array}
\end{aligned}
$$

\section{Death knows not who to kill}

\section{Association}

The use of hyperbole is very common with satirists. This involves exaggerated descriptions, attributions to people or things and values or qualities far beyond their actual state or appearances. For instance, Prince Rafilu is shocked to hear Salu his brother, Yunusa and Chief Ibrahimu discussing how they falsely testified against King Jùbìrílù . He tells them:

$$
\begin{aligned}
& \text { Gbogbo aiye ni ó gbo'yi . Ojú nyin rèe é } \\
& \text { Yunusa! Ibrahimu! Salu-egbon mi!... } \\
& \text { (pg. 77) } \\
& \text { (The whole world will hear this. Here you } \\
& \text { are, Yunusa! Ibrahimu! Salu - my } \\
& \text { brother...) }
\end{aligned}
$$

It is quite impossible for Rafilu to go round the whole world to expose the wicked men. What he means is that he will blow the incidence open to everyone around.

İdààmú Páàdì Mínkáilù is a tragic play, as a result, it is inevitable for the writer to use apostrophes - a figure of speech in which a person, present or otherwise, dead or an inanimate object, is directly addressed by a speaker to invoke them as witness, pity, praise or blame them . In the curtain speech by Mínkáílù, he says to the corpse of Setilu:

...Un lo se ti'iku fi mu o lo Setilu, iku da o legbodo iku ти o lo... 


$$
\text { (pg. 91) }
$$

(That is why death snatched you away Setilu, death cut your life short, and took you away)

This speech shows the general belief about the aftermath of the death of a righteous person.

The nucleus of the satire in the text is the position and role of the Catholic priest, especially as it concerns confession as an act of penance. When Yunusa is expressing his (mock) annoyance about Mínkáí lù's trip to Ibadan with Seti lu's 'body', Saratu (Setilu's wife) and the $£ 20,000$ meant for construction, king Jubirilu tries to placate him. Metonymy, a figure of speech whereby things, persons or circumstances are not referred to by their real names, but rather by their attributes or things associated with them, is seen in the kings words that:

$$
\begin{aligned}
& \text { K'o le da'a na ni, Paadi loun nse-un. } \\
& \text { (It is for the good of all, he is being } \\
& \text { Padre). }
\end{aligned}
$$

\section{Contrasts}

Paradox is a type of contrast used in literary pieces. Others are irony and epigram. A paradox is a figure of speech in which a statement may appear absurd, but when viewed vividly, it will be seen to be full of wisdom . An example of this is Sufianu's ridiculous statement to Prince Rafilu when the prince comes to Mínkáílù's vicarage to pluck aanges. He says:

\section{....S'emi ni mo so pe mo losan yi? Iwo lo si ji $i$ ka. Han-in iwo t'o o ka'san mi lo ye ko'o mu mi. Ole l'o nтu oni-nkan l'ode oni}

(Am I not the one who says I am the owner of this orange? You are the one who stole them. Yes! It is you who have stolen them that is supposed to arrest me. It is the thief who arrests the owner these days).

Rafilu knows that Sufianu (the 'fool') is referring to king Jubirilu his father, who is working with the police detectives in their search for the culprits of the attempted robbery and murder, whereas Salu, Rafilu's brother is one of the hoodlums. While Saratu who is present at the scene does not understand Sufianu's statement; Rafilu does. Rafilu tries to exonerate his father by replying Sufianu thus:

Nje, o ye mi o. Emi ki i sole o. Baba wa o si ko wa niru eyi ti e wi-un...

\section{(pg. 37)}

(Well then, I understand what you mean. I am not a thief. Our father never taught us such things as you imply...)

What Sufianu does here, as is wont of jesters, fools and parodists, is a diplomatic way of interrogating Rafilu to know if his father the king is aware, and consent to the fact that Prince Rafilu is a gangster. This is evident in Sufianu's epigramic (a witty, brief and pointed statement that expresses much in few words) statement after shame-faced Rafilu's exit.

Sufianu: Hèn-hèn-èn. Adegboye
lolopa-inu.

Emi Sufianu lolopa ode! Eni ti mo ba si $m u \ldots$

(pg. 38)

(That is it. Adegboye is the detective

I, Sufianu is the police. Whoever I catch...)

Sufianu's statement to the effect that he is also a detective (though taken to be a fool) is very true. This is because he appears to know the culprits already.

\section{Other Literary Devices}

Word-play, the juxtaposition of lexical terms that are similar in shape, is one of the literary devices used in the play. The intention is to bring about verbal dexterity . This device is seen in Sufianu's lackadaisical response to

Mínkáílù's explanation that the Oremus pro Pontificat nastro pio is awesome, and must be sang with reverence. Sufianu replies:

...nigbati Sufianu ò ba je ninu owo re ,
àgunlá, àgun-tete, àg'ewekó-ko ja
fürùpomù!

(pg. 51)

$$
\begin{aligned}
& \text { (...when Sufianu does not feed from his } \\
& \text { money, let whatever can, happen to him) }
\end{aligned}
$$

"Àgunlá" is an expression used by the Yorùbá to mean 'I do not care', 'Who cares?' or 'Let the worst happen' . Here, Sufianu is giving it a different meaning which is 'a -gun-ilá' (climbing an okro stem ). By this, he is able to 'play' with climbing tètè (spinach) and ewéko (plants), resulting in "agun-la, agun-tete' ag'eweko'. "Furupomu!" in the second line above is an onomatopoeia. It is the sound that a person falling from a tree accidentally is likely to make with his fall. The word-play is Sufianu's warning to the Padre that holding the Pope in reverence should be of little importance, compared to the disaster that is likely to follow, if the truth about Salu's confession is known, as the priest's silence is denying justice its due course.

Repetition is a device which refers to a deliberate mentioning of certain words or phrases more than once in a 
literary piece. The reason is for emphasis; in order to intensify on such words or phrases for effects. Repetition may be palilogic, anaphoric or anadiplosic [28]. An example of palilogic (deliberate) repetition is the word wahala (trouble/confusion/ misunderstanding/ uprising) used four times in two dialogues each, between Yunusa and Setilu (pg. 18). This is done intentionally by the playwright to hint that there will be conflict/confrontation between the two characters.

Soliloquy is a literary term which implies a character talking to him/ herself while alone. It is a calculated attempt to inform the audience/reader of what is going on in the mind of the speaker, about him/herself, or about others. In İdààmú Páàdì Mínkáilù, Mínkáílù initially accepts to bear the cross of being a member of Ejigbo Local Council committee, but at a point, the 'cross' brings him misery. He is torn between his position as a Catholic priest who represents Jesus Christ by listening to confessions and proclaiming forgiveness, and as a reliable elder who is expected to see to the welfare of the people in his community. In a soliloquy comparable with "Eloi, Eloi Lama sabacthani" by Jesus before his death (Mark 15:34), Mínkáílù asks a rhetorical question (in line 1) and laments:

Hùn-ùn-ù, irú idààmú wo ni mo kò sì yí o?

İwòfà r'oba lónà o s'àdúrà lábénú

Pé bóyá, orí a se é, irú òun a sì j’oba

İwòfà kò tètè mò

P'óri adé, kò jek'é;rú oba ó rogbo

İdààmú, olá kiì rò, koko ní i le

Òsùká báramu ko rerù àgbà

Hùn-Hùn-ùn ...

$$
\text { (pg. 43) }
$$

(Hun-un-un, what problem is this that I have put myself into. A pawned slave sees a king, he prays silently.

That may be destiny will allow him became a king

\section{Little does he know}

That it is not easy to bear the weight of royalty

The travails of wealth is not simple, it is always hard

A thick head-pad is insufficient to bear an elder's burden

Hùn-Hùn-ùn ...)

\section{Dialect, Loaned and Archaic words}

Adébáyò Fálétí, the playwright is a native of Òyó , an ancient capital-town of Yoruba land, now a town in present Òyó state of Nigeria, The Òyó dialect is very close to the (official) standard Yorùbá language . This is why many Yorùbá literary artists use it for aesthetic purposes in the ir works. Apart from this, Ėjìgbò, the location of the play is a small community in İbàràpá d ivision of Òyó state. This use of Òyó dialect (similarly used in Ìbàdàn area too) therefore, is realistic to the story line. An instance is this statement during the interrogation, where Salu replies:

\section{B'a ti ntele gbogbo re jo to fi doun nu-un}

(pg. 59)

(That is how we pile things up to make the whole)

"nù-un" (that) in this statement would have been niyen, were it to have been said in the standard Yorùbá language . Another one is the question asked Sálù by his mother:

Iya: Salu, ìwo kí páàdì mba wí ni?...

$$
\text { (pg. 74) }
$$

(Salu, are you not the one the Padre is talking to...?)

The negation $k i$ in the sentence would have been $k o ́$ in standard Yorùbá language.

Loan words from other languages are usually employed by literary artists for aesthetic effects and to lay emphasis on words or situations. Yunusa in the play under review, in a dramatic irony, talks like the pious Sahabah (a devoted Muslim) he ought to be, when he says:

Nwo te le e ni. Amó, asi-ta-nga-furulai o,

K'o oba o fori ese j'n епи ті o...

(pg. 28)

(He was being traced. But astagfirullah,

$$
\text { May Allah forgive my utterances...) }
$$

when Setilu is robbed in the council office.

'Astagfurullah' is an Arabic word which means 'Oh Allah, I seek your forgiveness'. Medoki (Hausa word meaning 'donkey rider') in page 4 and Ripétò / Rèpétò (Inspector) in page 36 , are other loan words.

Adebayo Fálétí is well known for his use of archaic or restricted words. Examples of this in İdààmú Páàdì Mínkáilù are Agódongbó (baby horse) in page 4 and İpètì (Strong rope) in page 76. The use of these words are meant not only to portray the poet, playwright or novelist as an 'elder', whose didactic teachings must be upheld, but also to show the beauty and variability of the Yorùbá lexicon. 


\section{Oral Poetry}

The oral poetry of the Yorùbá is very important in defining their traditional sociology, religion, culture and world-view. Some of the ones used in this play are ofo (incantations) and orin (songs).

Ofò is a restricted, esoteric and mystical poetic form that can be used by any individual who can obtain and master its use [29]. It is words of mouth backed with mystical powers to bring about the realization of the chanter's intention (positively or otherwise). Yunusa chants the ofò below when himself, Ibrahimu and Salu are swearing to an oath of secrecy, prior to the attempted robbery and murder. Jointly, they say:

Mo ba isin m'awo

Ki n le roju rere Olomi...

Mo jif'e je boju

Ki n'ma ba da'le e gbe awo...

Wiwo l'e nu awo $i$ wo...

(pg. 12)

(I got initiated with fingerlins

To seek the favour of the river goddess...

I wash my face with blood

So that I may not divulge the secrets of the cult

An initiate knows but never says...)

\section{Orin (Songs)}

A song is a form of communication, with rhythmic pattern, indicating a singer's state of mind at a particular time. Songs can be rendered ordinarily or accompanied with claps or musical ensembles. Sufianu is the only character who has no stake (directly) in the incidences of neither the robbery nor the attempted murder. As such, he is merry and cheerful. He imitates the tune of the Oremus pro Pontificat nostro pio thus:

\author{
Eje k'a-a \\ Gbadura fun Su-fi-i-a-a-a-nu-u \\ KO lorun ko d'e -e-mi-i-re-e siiii \\ Ko le pe fun Min-ka-a-a-i-lu-u \\ Ki o-o si le maa je-e, k'oo-o-le maa-mu-u \\ Ki o-o si le maa yinbon idi-i-i \\ ...ku!ka!ku!... Aamin
}

(pg. 49)

\section{(Let us Pray for Sufianu}

May the Lord preserve his life

So that he may live long for Minkailu

So that he may eat, so that he may drink

So that he may fart...

$$
\text { ...ku!ka!ku !... Amen) }
$$

The purpose of the song (as far as Sufianu is concerned), is to make a mockery of the 'foolishness' in praying for the Pope, who has 'no direct relevance to the welfare of neither the priest nor the congregation'. In essence, Sufianu means to point out the stupidity in shielding (wicked) Salu's confession at the detriment of the lives of innocent people like Rafilu and Setilu. This also affects the happiness of Jubirilu and his wife and that of Saratu, Setilu's wife

\section{Conclusion}

Adébáyò Fá létí in this play under study satirizes the conflicting roles of the Catholic priest in the church, and his social duties and responsibilities. This, the playwright is able to achieve to some extent, especially with the use of the comic character; Sufianu. Sufianu's speech lines are the major dialogues which portray the intention of the playwright. His speeches and those of the other characters are literarily examined in this paper, to bring to the fore, the peculiarity in the language used for this religious satire, and to reveal the real message of the play . Fálétí attempts to be optimal in the ridicule of clerics and other people who appear religious, but are either not personally convinced of their religious callings, or are outright spiritually dubious. However, we found him (with this play) to be biased against Catholic (Christians) than to Muslims generally. Though Fálétí is also a Christian, his stand is likely due to having no deep or enough knowledge about Catholicism in the light of the plurality of Christianity as evident in the several Christian denominations in Nigeria especially, and also globally. We say this because the role of the priest in the sacrament of penance is to represent Christ as the only one who can forgive sins. The proclamation of forgiveness is to heal and restore the morally and/or physically sick, to full communion with Christ and the Church. This is to enable such person to continue to participate in the (Catholic) mission. This does not stop the confessor from going to hand himself/herself over to appropriate authority to face punishment (even if it is death penalty). This is because his/her salvation is guaranteed (by the blood of Jesus Christ) after his initial remorse and confession. 
[1] Osisanwo, W., 2003. Introduction to Discourse Analysis in Pragmatics.Femous-Fetop Publishers. pp: 3.

[2] Osisanwo, W., 2010. Communication, Politics and the Use of English. OYE: Ogun Journal of Arts,(21): 12-27.

[3] Halliday, M.A.K. 1978. Language as Social Semiotics: The Social Interpretation and Meaning. Edward Arnold, pp: 23

[4] Adeniran, Adekunle 2010. Multilingualism on the Cross - A Sociolinguistic Exploration OYE: Ogun Journal of Arts, (16): $28-45$.

[5] Ibid

[6] Levinson, S C., 2003. Pragmatics. Cambridge: Cambridge University Press. pp: xii

[7] Mey, J. L. 2004. Pragmatics - An Introduction. Blackwell Publishers. pp.13.

[8] Nchikogwa, J.O. 2003. The Essentials of Literature. ABIC Books. pp: 11.

[9] Atanda, J.A. 1996. The Yoruba People: Their Origin, Culture and Civilization. The Yoruba: History, Culture and Language. Lagos: J.F. Odunjo Memorial Lectures Organizing Committee. pp 3-36

[10] Akintoye, S.A. 2010. A History of the Yoruba People. Dakar: Amalion Publishing

[11] Atanda, J.A, op. cit.

[12] Fafunwa, Aliu Babatunde. 2008. Eyin Ara e je Ka Gbe Yoruba Laruge. Ede Yoruba Lode Oni: Iwe Apileko Nipa Ajo Idagbasoke Imo Yoruba. Lagos: Macmillian Nigerian Publisher. pp 1-10

[13] Falola, Toyin. 2012. Atlantic Yoruba and the Expanding Frontiers of Yoruba Culture and Politics. 2012 J.F Odunjo Memorial Lectures. Uniiversity of Ibadan: Department of Linguistics and African Languages.

[14] Sotunde, F.I. 2009. Yoruba Proverbs and Philosophy.
Abeokuta: Damsan Nig. Co.

[15] Adagbada, Olufadekemi, 2013. Ose ti Eto Ijoba ati Ihuwasi Awujo n se fun Idagbasoke Ede ati Asa Abinibi Yoruba. Commissioned Paper Presented for the UNESCO World Language Day 2013 for Lagos State. On tbe 21st of February, 2013.

[16] Oshitelu, G.A. 2006. African Religions, Modernism, Postmodernism and World Religions. Wole Soyinka at 70 Festschrift, Eds., Adelugba, Dapo., Dan Isevbaye, J.E. Ifie. 10.Lace Occasional Publication, pp. $942-989$.

[17] Olatunji, O. O., 1984. Features of Yoruba Oral Poetry. Heinemann Publishers. pp. 8.

[18] Oshitelu, G.A. 2006. op. cit.

[19] Isola, A 1985. Abe Aabo. Onibonoje Press.

[20] Awoyale, O. 1983. Alàgbà Jeremíyà . Ibadan: Onibonoje Press.

[21] Adejumo A 2007. Satire as a Form of Social Control: Its Manifestations in Yorùbá Ritual and Festival Songs. ORITA: Ibadan Journal of Religious Studies (1), 69: 27- 40.

[22] ibid

[23] ibid

[24] Encyclopaedia Britannica.

[25] Faleti, A. 1972. Idaamu Paadi Minkailu. Onibonoje Press.

[26] Al-Jibaly (n.d) Our Precious Sprouts: Islamic Regulations for Newborns. Al-Kitab \& Sunnah Publishing. pp. 28.

[27] Olunlade, T.,1999. Agbeyewo Eko Ifa. Fola Printing and Publishing pp: 1

[28] Nchikogwa, J.O. 2003. op. cit.

[29] Olatunji, O. O., 1984. op. cit. 